\title{
Use of two new formulations as bovine embryo manipulation solution
}

\author{
Flavio Guisseli Lopes ${ }^{1}$, Eduardo Paulino da Costa ${ }^{1}$, Vanessa Lopes Dias Queiroz-Castro ${ }^{1, \S}$, \\ Emilio Cesar Martins Pereira ${ }^{1}$, José Domingos Guimarães', Saullo Vinicius Pereira Alves ${ }^{1}$, \\ Carlos Antonio Carvalho Fernandes ${ }^{2}$, Luiz Sérgio Almeida Camargo ${ }^{3}$, Laercio dos Anjos Benjamim ${ }^{1}$ \\ ${ }^{1}$ Veterinary Department, Federal University of Vicosa, Peter Henry Rolfs Avenue, Viçosa, Minas Gerais, Brazil. \\ ${ }^{2}$ José do Rosário Vellano University (UNIFENAS), Alfenas, Minas Gerais, Brazil. \\ ${ }^{3}$ Embrapa Gado de Leite, Juiz de Fora, Minas Gerais, Brazil.
}

\begin{abstract}
This study aimed to evaluate the effect of two Embryo Manipulation Solutions (EMS and EMS supplemented) in maintenance of the viability of embryos, initially using structures derived from mice (first phase). Next, the efficiency of these solutions in routines of bovine embryo transfer was evaluated (second stage). Mice embryos were used in the stages of early blastocyst, and compact morula grades I and II. These embryos were initially randomly distributed and maintained for four hours in three solutions: Modified phosphate buffered saline (PBS; Control); EMS (treatment 1), and EMS supplemented (treatment 2). Subsequently, they were cultured in TCM 199 medium and evaluated in terms of total number of cells, morphometric characteristics, ultra structural aspects, detection of cell apoptosis, and quantification of Hsp 70.3 gene expression. In the second phase, these same solutions were tested in the transfer of quality I and II bovine embryos (excellent and good). These embryos were transferred fresh to 58 recipients. The results showed that the total number of cells in embryos expanded blastocyst (ExB), the number of apoptotic cells, the cell, nuclear, nucleolar diameter and the nucleus/nucleolus ratio was similar among the treatments. The pregnancy rate shown on second phase was also similar. However, the EMS supplemented expressed more Hsp 70.3 than EMS. The expression of Hsp 70.3 was also greater for embryos in EMS than that of EMS supplemented. The McII embryos, EMS and EMS supplemented samples also expressed more Hsp 70.3 compared to control embryos. In conclusion, the tested solutions can be used in routine embryo transfer techniques, replacing modified PBS solution as an effective media in maintaining embryo viability.
\end{abstract}

Keywords: cell apoptosis, Hsp 70.3, mice.

\section{Introduction}

The improvement of the techniques involved in the process of in vitro production (IVP) of embryos is of fundamental importance to the study and understanding of biological mechanisms underlying embryonic development. The choice of media and energy substrates has an important impact on the development and viability of embryos (Vanroose et al., 2001).
According to Donnay and Leese (1999) energetic substrates, such as piruvate, glucose, lactate and amino acids play an important role in embryo development, explaining the use of different embryo manipulation and culture media.

During embryonic development, specifically in the preimplantation phase, genes are expressed in the blastocyst stage that are responsible for the processes that occur during cell differentiation and the implantation phase, an event that has a high percentage of embryonic mortality (Ponsuksili et al., 2002). Thus, any modification in culture conditions could directly affect embryo quality (Rizos et al., 2003). Even brief exposure to the manipulation medium, an average period of four hours, is sufficient for the occurrence of molecular and morphological changes (Gordon, 1994; Bavister, 1995). There are evidences showing that culture conditions have an impact on pre and postimplantation development and possibly the future health of the offspring (El Hajj and Haaf, 2013; Mantikou et al., 2013).

Increase in the number of apoptotic cells, alteration of gene expression, and ultra-structural modifications are examples of these changes (Rizos et al., 2003; Lonergan et al., 2003). Apoptosis, despite being regarded as a normal process in embryos during the preimplantation stage (Byrne et al., 1999), when occurs excessively, can lead to impairment of embryonic development (Levy et al., 2001). The proteins belonging to the family of the Hsp of 70 kilodaltons $(\mathrm{kDa})$ is expressed as a reflection of cell stress (Pedersen et al., 2005). This protein is one of the first to be produced during embryonic development and is of great importance for cell function (Zhang et al., 2011). According to Lane and Gardner (1997), normal fetal development is dependent on the total number of cells in the embryo. Mori et al. (2002) and Hoelker et al. (2006) reported a positive correlation between the total number of cells and diameter of bovine embryos produced in vitro. Thus, the total number of cells is frequently used as a parameter to evaluate the quality of embryos (Viuff et al., 2001; Pereira et al., 2005; Costa et al., 2010).

The manipulation solution routinely employed in conventional embryo transfer (ET) in cattle is modified phosphate buffered saline (PBS) (Whittingham, 1971).

According to the success obtained by Whittingham (1971), few studies have been carried out in 
order to find more appropriate and stable solutions for the manipulation of embryos in different animal species. However, modified PBS is subject to possible changes in composition, such as $\mathrm{pH}$ variations, formation of precipitates of calcium chloride and magnesium chloride, especially when stored for a long time in ambient temperature and light (Gordon, 1994; IETS, 1998). Therefore, this media should be stored in a low light, in a refrigerated environment (minimum temperature of $4^{\circ} \mathrm{C}$ ), in order to prevent degradation of some components such as pyruvate (Taylor, 1984).

Considering these aspects, it would be desirable to use a media that is able to maintain the viability of the embryos, more stable, with minimum possibility of alteration during storage, even at room temperature. In view of this fact, the medium tested in the present study met these requirements, being therefore a more appropriate medium for use, since its stability.

The present study was designed to evaluate cleavage rate, diameter, morphological aspects, cell apoptosis, and gene expression of $\mathrm{Hsp}_{\mathrm{s}} \mathrm{70.3}$ in mice embryos, after maintenance in different manipulation solutions and subsequent in vitro culture. At a later stage, bovine embryos were manipulated in these solutions and transferred to the bovine recipients, and we evaluated pregnancy rate to determine if it was feasible to substitute the media conventionally used for simpler and more stable solutions that could be stored at room temperature.

\section{Material and Methods}

The experiment was conducted in two phases to evaluate the effects of embryo manipulation solutions. In Phase I, mice were used, which are commonly used as an experimental model in studies of in vitro embryo production. The solutions that maintained embryo viability in this phase were tested later in bovine embryos, which constituted Phase II.

Phase I was conducted at the Animal Reproduction Laboratory of the Federal University of Vicosa (UFV), using mice embryos of Mus musculus species, of the Swiss albino strain. Phase II involved bovine embryos produced in vivo that were maintained in the tested solutions and subsequently inoculated in bovine recipients.

All experimental procedures were performed in accordance with the ethical principles adopted by the National Research Council, upon authorization from the Animal Ethics Committee of UFV, processed 10/2006.

\section{Phase I}

Two manipulation solutions used for collection and manipulation of embryos were tested: an embryo manipulation solution (EMS): sodium chloride $(0.1027$ mol L $\left.{ }^{-1}\right)$, potassium chloride $\left(0.0040 \mathrm{~mol} \mathrm{~L}^{-1}\right)$, calcium chloride $\left(0.0018 \mathrm{~mol} \mathrm{~L}^{-1}\right)$; sodium lactate $\left(0.0277 \mathrm{~mol} \mathrm{~L}^{-}\right.$ ${ }^{1}$ ); and EMS supplemented (the same formulation of EMS plus $0.0003 \mathrm{~mol} \mathrm{~L}^{-1}$ sodium pyruvate). The modified PBS served as the control (Whittingham, 1971).

The EMS and EMS supplemented solutions were produced and adjusted with glucose to $290 \mathrm{mOsm}$ with the aid of an osmometer (Osmette $A \circledR$ Automatic Osmometer) and the $\mathrm{pH}$ was adjusted to 7.2-7.4. All reagents used for the production of manipulation and culture solutions were previously tested for cell culture and were from Sigma Chemical Co. ${ }^{\circledR}$ (St. Louis, MO). The antibiotics used for EMS and EMS supplemented solutions were the same as used in the modified PBS (Whittingham, 1971), in which 50mg Streptomycin sulfate and $100 \mathrm{UI} / \mathrm{mL}$ of G Sodic-Penicillin were added.

Following the conventional superovulation protocol (Rafferty, 1970), mice embryo donors were induced to superovulation and mated. After $60-80 \mathrm{~h}$ following mating, the donor females were euthanized for collection of embryos, which was accomplished by washing the uterine horns. The media tested were used for the washing.

Only embryos in the stages of early blastocyst (EB), and compact morula grades I (McI) and II (McII) were used, and were randomly distributed into three treatments: T1 - modified PBS (Control); T2 (EMS); and T3 (EMS supplemented). The embryos from each treatment were maintained in four-well plates (Nunc ${ }^{\circledR}$ $\mathrm{A} / \mathrm{S}$ ), for four $\mathrm{h}$, in the manipulating solutions at $37^{\circ} \mathrm{C}$ plus $0.4 \%$ bovine serum albumin, fraction $\mathrm{V}$.

After the end of the manipulation period, the embryos were classified according to their stage of development and embryo quality was assessed (IETS, 1998) using a stereoscopic microscope (Olympus Optical ${ }^{\circledR}$, SZ-40 model/SZ-ST) with a 10X eyepiece and $4 \mathrm{X}$ objective, which was used throughout the experiment. After being classified, embryos were transferred to media and cultured in four-well plates (Nunc ${ }^{\circledR} \mathrm{A} / \mathrm{S}$ ), for $10 \mathrm{~h}$ in a modified TCM-199 culture medium (Costa et al., 1997) in an incubator oven (Jouan ${ }^{\circledR}$, IG $\left.150 \mathrm{Model}\right)$ at $37^{\circ} \mathrm{C}$ in an atmosphere of $5 \%$ carbon dioxide, $95 \%$ atmospheric air, and at $95 \%$ humidity.

Following the culture period, the embryos were transferred and washed in a hollowed plate in modified Talp-Hepes medium at $37^{\circ} \mathrm{C}$ (Costa et al., 1997), and were classified again. After the culture, 70 embryos in the initial stage of expanded blastocyst (ExB) were randomly separated and submitted to morphometric evaluation in accordance with the methodology of Fukui and Ono (1989), with the aid of the stereoscopic microscope.

This evaluation was carried out in three periods with the aid of the same microscope, which had a micrometric reticulum (1 $\mathrm{mm}$ per side with 100 subdivisions) in the $10 \mathrm{X}$ eyepiece and $4 \mathrm{X}$ objective. The diameter of embryos at the time of collection, at the end of the manipulation period, and at the end of the culture period was recorded. After taking measurements, the means and standard deviations were calculated using the appropriate correction factor for the determined increase (Hoffmann, 1987).

The procedures of Costa (1994) were adopted for evaluation using transmission electron microscopy (TEM). For each treatment, five embryos were used, which were in ExB stage following the culture period. After the inclusion of the embryos (Costa, 1994), semithin sections $(0.5 \mu \mathrm{m})$ were obtained using a glass knife on an ultramicrotome. The best sections were selected 
under optical microscopy to perform the ultrathin sections (60-70 nm) using a diamond knife. These ultrathin sections were stained with uranyl acetate and lead citrate and evaluated using TEM (Zeiss ${ }^{\circledR}$, EM 109 model).

For the detection of cell apoptosis and to determine the total cell number, the TUNEL (Terminal Transferase Mediated Uracil Nick End Labeling) technique and the APO-BrdU ${ }^{\mathrm{TM}}$ Assay Kit (Invitrogen ${ }^{\circledR}$, CA, USA) were used. For each treatment, five embryos were used, which were in the ExB stage after culture. The embryos from each treatment were fixed on slides and processed according to the manufacturer's instructions (Promega ${ }^{8}$, WI, USA). The slides were analyzed on a fluorescence microscope and observed through a filter $(520 \pm 20 \mathrm{~nm})$ with a $40 \mathrm{X}$ objective. Cells that were green were considered TUNEL-positive cells (i.e., apoptotic cells). In this step, the total number of cells present in the embryos was also counted.

Quantitative variables (TEM and cell apoptosis) were submitted to tests for normality (Lilliefors) and homoscedasticity (Cochran), and subsequently to an analysis of variance (ANOVA). When significance was detected, Duncan's comparisons of means test was carried out. When the assumptions of normality and homoscedasticity were not attained after the appropriate transformations, data were submitted to the nonparametric Kruskal-Wallis test (UFV, 1999).

For the quantification of gene expression, the RT-PCR technique was used in real time, evaluating two genes, one endogenous (BActin) and one related to heat stress (Hsp 70.3), as summarized in Tab. 1. For each manipulation solution, tested three samples of embryos (10 in each sample), in duplicate, classified at the time of collection in EB, McI, and McII stages, totaling 30 embryos per treatment. After the end of the culture period, the embryos that were in the ExB stage were also evaluated.

The RT-PCR reactions in real time were carried out in an ABI Prism 7300 Sequence Detection Systems thermocycler (Applied Biosystems, CA, USA), using SYBR Green ${ }^{\circledR}$ PCR Master Mix Kit (Applied Biosystems, CA, USA), according to the manufacturer's recommendations. The reactions contained $12.5 \mu \mathrm{L}$ PCR MIX, $5 \mu \mathrm{L}$ cDNA, primer, and water, totaling $25 \mu \mathrm{L}$. The concentrations of primer and cDNA were previously optimized for each gene.

Data obtained were analyzed by REST $^{\circledR}$ program (Pfaffl et al., 2002), available at http://www.wzw.tum.de/gene-quantification, which uses the Pair Wise Fixed Reallocation Randomization Test ${ }^{\circledR}$ model to compare expression between the samples from the treatments.

Table 1. Sequence of primers and annealing temperatures specific to each gene evaluated.

\begin{tabular}{llll}
\hline Genes & & Primers $\left(5^{\prime}-3^{\prime}\right.$ sequence) & AT $\left({ }^{\circ} \mathrm{C}\right)$ \\
\hline BActin & Forward & 5' TCTTGGGTATGGAATCCTGTGGCA 3' & 60,1 \\
& Reverse & 5' AGATGTGGATCAGCAAGCAGGAGT 3' & 59,5 \\
\hline \multirow{2}{*}{ ssp70.3 } & Forward & 5' CGCTCGAATCCTATGCCTTCAACA 3' & 58,9 \\
& Reverse & 5' GCACTTGTCCAGCACCTTCTTCTT 3' & 59,4 \\
\hline
\end{tabular}

AT: Annealing temperature.

\section{Phase II}

The solutions that maintained mice embryo viability were tested later in bovine embryos. Fifty-eight crossbred heifers with body weight $>350 \mathrm{~kg}$ were used as recipients of embryos. Throughout the experimental period, the animals were maintained in paddocks with Brachiaria brizantha grass, mineral supplementation, and water ad libitum. All heifers that were between days 7 and 17 of the estrous cycle, or had the corpus luteum previously detected by ultrasound or transrectal palpation, received $0.53 \mathrm{mg}$ sodium cloprostenol (Ciosin $^{\circledR}$; Schering-Plough Brazil Ltd, Brazil) through intramuscular injection (IM). This medication was administered to the recipients $24 \mathrm{~h}$ before the application of the donors during the process of superovulation. The recipients that expressed estrus $24 \mathrm{~h}$ before and through $24 \mathrm{~h}$ after the donors were considered synchronized and suitable for embryo transfer.

Four Holstein cows with body weight $>500 \mathrm{~kg}$ were used as embryo donors. Animals that exhibited estrous cycles with regular intervals $(21 \pm 3$ days $)$ and were clinically normal on gynecological examination were selected. The animals received the same diet throughout the experimental period. The animals were maintained in paddocks of Brachiaria brizantha grass, in the presence of a ruffian, with mineral supplementation and water ad libitum.

Treatment of the donors initiated on predetermined days, with the application of a progesterone intravaginal device (CIDR $\AA$; Pfizer Animal Health, Brazil). On the following day, $3 \mathrm{mg}$ estradiol benzoate (RIC-BE®; Syntex S.A.; Argentina) was administrated via IM injection.

Five days following the application of the progesterone device, the superovulation protocol was initiated with the administration of decreasing doses of FSH-p hormone (Folltropin-V®; Vetrepharm Inc.; Canada) via the IM route at intervals of $12 \mathrm{~h}$ for a total of eight applications (total concentration from 140 to 200 IU). With the seventh application $0.53 \mathrm{mg}$ sodium cloprostenol (Ciosin $₫$; Schering-Plough Brazil Ltd, Brazil) was applied to induce luteolysis. At the eighth application, the progesterone intravaginal device was removed. After the detection of estrus, two inseminations were performed, the first between 10 and $12 \mathrm{~h}$, and the second between 20 and $24 \mathrm{~h}$ after the onset of estrus.

Embryos were collected by non-surgical method between the sixth and eighth day following the onset of estrus. The manipulation solutions to be evaluated were preheated to $37^{\circ} \mathrm{C}$ and used to wash the uterine horns.

In the farm laboratory, we searched for embryos 
with the aid of a stereoscopic microscope (Olympus Optical ${ }^{\circledR}$, SZH-ILLB model) with $15 \mathrm{X}$ magnification. Once found embryos were classified according to stage of development and embryo quality (IETS, 1998) and were transferred to dish and maintained for a maximum period of four hours. The manipulation solutions were EMS supplemented, EMS, and modified PBS, and were previously equilibrated $\left(37^{\circ} \mathrm{C}\right)$ with the addition of $0.4 \%$ bovine serum albumin, fraction $\mathrm{V}$.

The ET was carried out fresh (i.e., the embryos were not frozen). Only quality I and II embryos (excellent and good) were collected and transferred. The recipients were randomly distributed into three treatments: T1 - modified PBS (Control), T2 (EMS), and T3 (EMS supplemented). Embryo inovulation was performed by the transcervical method.

Pregnancy diagnosis was performed on the 28th day after detection of estrus in the recipients through ultrasonography (Pie Medical ${ }^{\circledR}$, Scanner 100
Falco model), connected to a transducer for $6 / 8 \mathrm{MHz}$ bifrequencial endorectal evaluation. For statistical analysis of pregnancy rate, the data were compared in contingency tables and analyzed by chi-square test at a 5\% significance level (Sampaio, 2002).

\section{Phase I}

\section{Results}

A total of 1.542 mice embryos were recovered and sorted between the experiments. The total number of cells in embryos in the ExB stage was similar among the treatments $(\mathrm{P}>0.05)$, as shown in Table 2. The mean diameter of the embryos in EB stage showed a higher growth rate $(\mathrm{P}<0.05)$ when maintained for a period of four hours in the EMS and EMS supplemented solutions, compared to the control group (modified PBS) (Tab. 3). However, the embryos in McI and McII stages showed no increase in diameter $(\mathrm{P}>0.05$; Tab. 3$)$.

Table 2. Means ( \pm standard deviations) of the total number of cells in mice embryos in the expanded blastocyst stage after the maintenance in manipulation solution and subsequent in vitro culture, in the different treatments.

\begin{tabular}{lcc}
\hline Treatments & Total of embryos (N) & $\mathrm{X} \pm \mathrm{SD}$ \\
\hline Control & 35 & $54.1 \pm 10.7$ \\
EMS & 35 & $55.5 \pm 11.4$ \\
EMS supplemented & 35 & $53.2 \pm 9.6$ \\
\hline
\end{tabular}

Control: modified PBS (Whittingham, 1971). X = mean; SD = standard deviation. The differences were not significant $(\mathrm{P}>0.05)$ among the treatments according to the Duncan test.

Table 3. Diameter (micra) of mice embryos in early blastocyst, compact morula grades I and II stages after the collection, maintenance in manipulation solution, and subsequent in vitro culture, in the different treatments.

\begin{tabular}{lccc}
\hline Treatments & $\begin{array}{c}\text { Collection }(0 \mathrm{~h}) \\
\mathrm{X} \pm \mathrm{SD}\end{array}$ & $\begin{array}{c}\text { Maintenance }(4 \mathrm{~h}) \\
\mathrm{X} \pm \mathrm{SD}\end{array}$ & $\begin{array}{c}\text { Culture }(10 \mathrm{~h}) \\
\mathrm{X} \pm \mathrm{SD}\end{array}$ \\
\hline (EB) & & & $96.7 \pm 10.5^{\mathrm{a}, \mathrm{B}}$ \\
\hline Control & $73.7 \pm 7.8^{\mathrm{a}, \mathrm{A}}$ & $74.4 \pm 7.0^{\mathrm{a}, \mathrm{A}}$ & $97.4 \pm 10.8^{\mathrm{a}, \mathrm{B}}$ \\
EMS & $74.4 \pm 8.3^{\mathrm{a}, \mathrm{A}}$ & $76.5 \pm 7.7^{\mathrm{a}, \mathrm{b}, \mathrm{A}}$ & $97.7 \pm 9.3^{\mathrm{a}, \mathrm{B}}$ \\
EMS supplemented & $74.7 \pm 7.2^{\mathrm{a}, \mathrm{A}}$ & $78.9 \pm 7.3^{\mathrm{b}, \mathrm{A}}$ & \\
\hline (McI) & & $90.2 \pm 8.9^{\mathrm{a}, \mathrm{B}}$ \\
Control & $71.7 \pm 4.6^{\mathrm{a}, \mathrm{A}}$ & $71.3 \pm 5.0^{\mathrm{a}, \mathrm{A}}$ & $91.2 \pm 8.3^{\mathrm{a}, \mathrm{B}}$ \\
EMS & $71.7 \pm 5.4^{\mathrm{a}, \mathrm{A}}$ & $73.0 \pm 6.7^{\mathrm{a}, \mathrm{A}}$ & $92.6 \pm 6.9^{\mathrm{a}, \mathrm{B}}$ \\
\hline \multicolumn{1}{c}{ (McII) } & $71.3 \pm 5.0^{\mathrm{a}, \mathrm{A}}$ & & $84.0 \pm 10.5^{\mathrm{a}, \mathrm{B}}$ \\
\hline Controle & & $71.7 \pm 5.4^{\mathrm{a}, \mathrm{A}}$ & $86.4 \pm 10.0^{\mathrm{a}, \mathrm{B}}$ \\
$\quad$ EMS & $71.0 \pm 6.1^{\mathrm{a}, \mathrm{A}}$ & $73.0 \pm 6.1^{\mathrm{a}, \mathrm{A}}$ & $86.1 \pm 9.4^{\mathrm{a}, \mathrm{B}}$ \\
\hline
\end{tabular}

Control: modified PBS (Whittingham, 1971). X = mean; SD = standard deviation; EB: early blastocyst; McI: grade I compact morula; McII: grade II compact morula. Means with different lowercase letters in the same column indicate difference $(\mathrm{P}<0.05)$ among treatments for the EB, McI (Tuckey test) and McII (Kruskal-Wallis test) stages. Means with different uppercase letters in the same line indicate difference $(\mathrm{P}<0.05)$ among treatments for the EB (Tuckey test), McI and McII (Kruskal-Wallis test) stages.

No difference in the cell, nuclear, nucleolar diameters and or the nucleus/nucleolus ratio was observed even after the maintenance for $4 \mathrm{~h}$ in the tested manipulation solutions $(\mathrm{P}>0.05)$, as compared to the control group (Tab. 4). No difference was observed among the treatments $(\mathrm{P}>0.05)$ in the number of apoptotic cells. Means and standard deviations for the different treatments were 38.0 \pm 10.7 (control), $37.1 \pm 11.4$ (EMS), and $40.0 \pm 9.6$ (EMS supplemented).

With the aid of REST ${ }^{\circledR}$ software, it was possible to perform comparisons among the treatments for gene expression of Hsp70.3 (Tab. 5). Considering the EB embryos, the EMS and EMS supplemented solutions expressed more Hsp70.3 than did control embryos $(\mathrm{P}<0.001)$. It was also found that EMS supplemented expressed 9.071 times more Hsp 70.3 than EMS $(\mathrm{P}<0.001)$. Similarly, for McI embryos, EMS and EMS supplemented samples expressed more than control samples $(\mathrm{P}<0.001)$. The expression of Hsp 70.3 was 3.007 times greater for embryos in EMS $(\mathrm{P}<0.001)$ than that of EMS supplemented. The McII embryos, 
EMS and EMS supplemented samples also expressed more Hsp70.3 compared to control embryos $(\mathrm{P}<0.001)$. A higher expression was observed for EMS supplemented than EMS $(\mathrm{P}<0.001)$

\section{Phase II}

No difference among treatments was found for pregnancy rate $(\mathrm{P}>0.05$; Table 6$)$.

Table 4. Means ( \pm standard deviations in micras) of the cell diameter, nuclear diameter, nucleolar diameter, and nucleus/nucleolus ratio in embryos in the early blastocyst stage after manipulation and subsequent in vitro culture in the different treatments.

\begin{tabular}{lcccc}
\hline & CD & ND & NLD & NNR \\
\hline Treatment & $\mathrm{X} \pm \mathrm{SD}$ & $\mathrm{X} \pm \mathrm{SD}$ & $\mathrm{X} \pm \mathrm{SD}$ & $\mathrm{X} \pm \mathrm{SD}$ \\
\hline Control & $15.0 \pm 7.1$ & $6.6 \pm 1.7$ & $2.4 \pm 0.6$ & $2.8 \pm 0.4$ \\
EMS & $25.6 \pm 10.5$ & $9.8 \pm 7.1$ & $2.5 \pm 0.3$ & $3.8 \pm 2.5$ \\
EMS supplemented & $17.3 \pm 7.6$ & $6.5 \pm 1.7$ & $1.7 \pm 0.6$ & $3.9 \pm 0.4$ \\
\hline
\end{tabular}

Control: modified PBS (Whittingham, 1971). X = mean; SD = standard deviation. CD: cell diameter, ND: nuclear diameter, NLD: nucleolar diameter; NNR: nucleus/nucleolus ratio; EB: early blastocyst; McI: compact morula grade I; McII: compact morula grade II. The differences were not significant $(\mathrm{P}>0.05)$ among the treatments by the Duncan test.

Table 5. Relative expression of $H s p 70.3$ gene among the samples of the treatments.

\begin{tabular}{lcccc}
\hline & & \multicolumn{3}{c}{ Relative expression } \\
\hline Gene & Samples & Cnt $v s$ EMS & Cnt $v s$ EMS suppl. & EMS vs EMS suppl. \\
\multirow{3}{*}{ Hsp70.3 } & EB & $1,421^{\mathrm{a}}$ & $12,889^{\mathrm{b}}$ & $9,071^{\mathrm{c}}$ \\
& McI & $4,129^{\mathrm{a}}$ & $1,373^{\mathrm{b}}$ & $3,007^{\mathrm{c}}$ \\
& McII & $20,959^{\mathrm{a}}$ & $9,217^{\mathrm{b}}$ & $2,274^{\mathrm{c}}$ \\
\hline
\end{tabular}

Means with different lowercase letters in the same line indicate difference among treatments $(\mathrm{P}<0.05)$ by $\mathrm{REST}^{\circledR}$ software. Cnt = Control: modified PBS of Whittingham (1971).

Table 6. Pregnancy rates in bovine recipients inoculated with fresh embryos, in the different treatments.

\begin{tabular}{lccc}
\hline Treatments & $\mathrm{N}$ & Pregnants $(\mathrm{N})$ & Pregnancy $(\%)$ \\
\hline Control $^{1}$ & 19 & 9 & $47.4^{\mathrm{a}}$ \\
EMS & 19 & 9 & $47.4^{\mathrm{a}}$ \\
EMS supplemented & 20 & 11 & $55.0^{\mathrm{a}}$ \\
\hline
\end{tabular}

${ }^{1}$ Control: modified PBS (Whittingham, 1971). $\mathrm{N}=$ number of animals. There was no difference among treatments $(\mathrm{P}>0.05)$, by the Chi-square test.

\section{Discussion}

The number of cells described in this study is similar that of previous studies. Alexandre (1978) and Evsikov (1996) reported cell means for cleavage rates of mouse embryos produced in vitro of $46.6 \pm 2.7$ and 60.5 \pm 1.4 , respectively. However, in vivo, Bowman and Mclaren (1970) and Smith and Mclaren (1977) observed cell means of $56.9 \pm 7.81$ and $44.8 \pm 3.2$, respectively. These data emphasize the influence that manipulation and culture media have on the development and quality of embryos.

Thus, it can be affirmed that the solutions tested (EMS and EMS supplemented) maintained the cleavage rate and consequently, the quality of embryos after four hours of manipulation. According to Lane and Gardner (1997), normal fetal development is dependent on the number of total cells of the embryo. Zhu et al. (2014) emphasize in their research the importance of this parameter since they found that grade III or IV embryos with 7-8 cells were better than grade I or II embryos with only 4 or 5 cells.

In the present experiment, the mean diameter presented by EB embryos, McI, and McII at the time of collection, at the end of the period of manipulation, and at the end of in vitro culture were within the normal range, in agreement with Bowman and Mclaren (1970) and Chung (1973). According to Lindner and Wright (1983), embryo diameter is the same during the morula and blastocyst stages, and increase occurs only in the expanded blastocyst stage, at which time there is a considerable increase in the diameter (1.2-1.5 times), and the zona pellucida is decreased by $1 / 3$ of its original thickness.

According to Rieger (1992) and Martin and Leese (1995), the pyruvate captured by the embryo presents different percentages of metabolization, in accordance with the phase of development. According to these authors, $44 \%$ is metabolized in the two-cell stage and $17 \%$ in the morula stage. After which, glucose becomes the substrate predominantly used. This fact validates the results of the present study, in which the size of the morula stage in the EMS and EMS supplemented treatments did not differ from that of the control (modified PBS). Thus, it is probable that the pyruvate made available by the tested solutions was not been fully used by the embryos in McI and McII. In addition, both solutions presented similar results in relation to the control, revealing them sufficient to 
maintain embryonic development at ideal rates.

However, the rate between pyruvate: lactate is essential for the balance of the oxidation/reduction potential (Morales et al., 1999) Butcher et al. (1998) also suggest that the pyruvate could be converted into alanine and act to remove ammonia from the embryo, playing a role in embryo protection. In addition, it acts degrading the exogenous hydrogen peroxide $\left(\mathrm{H}_{2} \mathrm{O}_{2}\right)$ and preventing the embryo from oxidative stress (Morales et al., 1999), which may justify the supplementation of pyruvate in the manipulation media.

The results of this study suggest that the tested solutions were able to promote sufficient metabolic stimuli to maintain the morphological characteristics of the embryos under normal conditions because the results were similar to the solution used in the control group. According to Knijn et al. (2003), the incidence of apoptosis was higher in embryos produced in vitro than in those produced in vivo, because embryos are subjected to adverse conditions, such as exposure to high culture temperatures for 7 days. Therefore, the increased incidence of cell death is an important indicator of embryo quality (Vanda Ele et al., 2007).

The manipulation media EMS and EMS supplemented were not able to reduce the number of apoptotic cells compared to the control group. Few studies in the literature separately report the incidence of apoptosis in early blastocyst, blastocyst, and expanded blastocyst stages; however, it is known that the largest quantity of apoptotic cells is found in the expanded blastocyst stage (Fabian et al., 2005; Fabian et al., 2007).

The results demonstrated a difference in the Hsp 70.3p expressed in EB, McI, and McII embryos after maintenance and subsequent in vitro culture in the different treatments. According to Lonergan et al. (2003), embryonic gene expression can be modified in response to environmental changes, which is probably an attempt of the embryo to stabilize its cellular function. Thus, the observed differences can be related to the use of the manipulation solutions. The culture medium is one of the factors that can modify the transcription activity of the Hsp genes (Sagirkaya et al., 2006; Lazzari et al., 2002).

Exposure to stressful situations results in morphological changes in the embryo. The redistribution of organelles in the cortical region, cytoplasmic aggregation, and vacuolization and rupture of the mitochondrial membrane and/or matrix can result in apoptosis and cell death (Li et al., 2000). Although an increased expression of Hsp70.3 in embryos maintained in EMS and EMS supplemented occurred, there was no impairment of embryonic development. Machado et al. (2013) observed that among the evaluated genes related to stress only Hsp 70 was different between in vivo and in vitro system and, unexpectedly, the in vivo system presented the highest quantity of Hsp. The authors pointed out that the Hsp 70 mRNA of the in vitro embryos in adverse conditions might be depleted more quickly in order to produce the protein in face of the stressful conditions. The EMS and EMS supplemented solutions are composed of energy substrates that have a positive effect on embryo development, such as glucose, lactate, and pyruvate (Dorland et al., 1992; Thompson, 2000; Riley and Moley, 2006).

Working with mice embryos, Beckmann et al. (1992) and Dix et al. (1998) found that minimum levels of Hsp70.1 and Hsp70.3 are necessary for the normal development of preimplantation embryogenesis. This may have occurred in the present study, because despite the increased expression of Hsp70.3 in the treatments, the characteristics of morphology and apoptosis of the embryos were not affected. This result is contrary to the findings of Fear and Hansen (2011), who indicated that in bovine embryos, the increase of Hsp demonstrated association with apoptosis and consequently, embryo death.

The pregnancy rates obtained in this experiment were similar to those observed by several researchers using the modified PBS for the manipulation of bovine embryos. Macmillan (1998) searched the published literature regarding bovine fresh ET and found an average of $43 \%$ pregnancy. Similar results were reported by Gioso et al. (2005) and Haas et al. (2007), who found pregnancy rates of $45.5 \%$ and $50 \%$, respectively.

The positive results are supported by the composition of the EMS and EMS supplemented solutions, which contain energy substrates that provide conditions for the normal development of the embryos. The EMS solution has glucose and lactate, whereas the EMS supplemented contains three energy substrates: glucose, lactate, and pyruvate.

The use of pyruvate was proposed because it is used by embryos during their development (Thompson, 2000). After blastulation, there is an increase the need for pyruvate, the lack of which could interfere with the viability of the blastocyst (Dorland et al., 1992).

Lactate is another component that allows embryo development from the single cell stage to the blastocyst (Bavister, 1995). Its interaction with pyruvate was described as essential for the balance of the oxidation/reduction potentials (Morales et al., 1999). The presence of glucose in the manipulation solution is justified by the necessity of its incorporation in the final stages of embryonic development. The greater consumption of glucose at this stage occurs in most species embryos IVP systems, a glucose uptake facilitates the production of better quality embryos reflecting in successful transfers. (Thompson, 2000; Gardner and Wale, 2013; Absalón-Medina et al., 2014).

The interaction of these substrates, contained in the proposed manipulation solutions, may have been responsible for the development of embryos, and consequently, for the satisfactory pregnancy rates found in this study.

\section{Conclusion}

The manipulation solutions (EMS and EMS supplemented) did not interfere in embryo cleavage rate, and can be used as a substitute for the modified PBS solution. It was concluded that the EMS supplemented solution favors the greater development of EB after the period of manipulation and subsequent in vitro culture. 
Although the solutions result in expression of a greater amount of $H s p 70.3$, they maintain the ultrastructural characteristics and the normal proportion of apoptotic cells of the embryos.

\section{Acknowledgements}

This work was supported by FAPEMIG Research Foundation of the State of Minas Gerais (4214 - FAPEMIG - CVZ - 1293/06).

\section{References}

Absalón-Medina VA, Butler WR, Gilbert RO. 2014 Preimplantation embryo metabolism and culture systems: experience from domestic animals and clinical implications. J Assist Reprod Genet, 31(4):393-409.

Alexandre H. 1978. Correlation between cytological and morphogenetic effects of acute X-irradiation of preimplantation mouse embryos cultured in vitro. $J$ Reprod Fertil, 53:399-402.

Bavister BD. 1995. Culture of preimplantation embryos facts and artifacts. Hum Reprod Update, 1:91-148.

Beckmann RP, Lovett M, Welch MJ. 1992. Examining the function and regulation of Hsp70 in cells subjected to metabolic stress. J Cell Biol, 117:1137-1150.

Bowman P, McLaren A. 1970. Cleavage rate of mouse embryos in vivo and in vitro. J Embryol Exp Morphol, 24, 203-207.

Butcher I, Coates A, Martin KL, Rutherford AJ, Leese HJ. 1998. Metabolism of pyruvate by the early human embryo. Biol Reprod, 58:1054-1056.

Byrne AT, Southgate J, Brison DR, Leese HJ. 1999 Analysis of apoptosis in the preimplantation bovine embryo using TUNEL. J Reprod Fertil, 117:97-105.

Chun SO. 1973. Volume changes during the preimplantation stages of mouse egg development. Yonsei Med J, 14:63-90.

Costa EP, Lopes FG, Pereira ECM, Queiroz VLD, Macedo GG, Almeida Neto JRM, Costa AHA. 2010 Nova técnica para contagem do número de células de blastocistos [in Portuguese]. Arq Bras Med Vet Zootec, 62:1507-1510.

Costa EP, Vale Filho VR, Nogueira JC, Ferreira AM, Guimarães JD, Costa AHA. 1997. Cultivo in vitro de ovócitos bovinos em diferentes sistemas: I efeito na maturação nuclear [in Portuguese]. Arq Bras Med Vet Zootec, 49:551-559.

Costa EP. 1994. Aspectos morfológicos (citológicos e ultraestruturais) e desenvolvimento de ovócitos de bovinos "in vitro" [in Portuguese]. Belo Horizonte, Brazil: Federal University of Minas Gerais. Thesis.

Dix DJ, Garges JB, Hong RL. 1998. Inhibition of hsp70-1 and hsp70-3 expression disrupts preimplantation embryogenesis and heightens embryo sensitivity to arsenic. Mol Reprod Dev, 51:373-380.

Donnay I, Leese HJ. 1999. Embryo metabolism during the expansion of the bovine blastocyst. Mol Reprod and Dev, 53:171-178.

Dorland M, Kruip TAM, Van Der Donk JA. 1992. Assessing day 7 bovine embryo viability by measuring the rate of nutrient uptake. J Reprod Fertil, 9:40.
El Hajj N, Haaf T. 2013. Epigenetic disturbances in in vitro cultured gametes and embryos: implications for human assisted reproduction. Fertil Steril, 99:632-641.

Evsikov V, Vagyna IN, Solomko AP. 1996. Mechanisms of cell number regulation in the periimplantation mouse blastocyst. J Exp Zool, 276:201-208.

Fabian D, Bukovská AV, Koppel P, Makarevich A, Chrenek J. 2007. Chronological appearance of spontaneous and induced apoptosis during preimplantation development of rabbit and mouse embryos. Theriogenology, 68:1271-1281.

Fabian D, Koppel KJ, Hyttel-Maddox P. 2005. Apoptotic processes during mammalian preimplantation development. Theriogenology, 64:221-231.

Fear JM, Hansen PJ. 2011. Developmental changes in expression of genes involved in regulation of apoptosis in the bovine preimplantation embryo. Biol Reprod, 84:43-51

Fukui Y, Ono H. 1989. Effects of sera, hormones and granulose cells added to culture medium for in vitro maturation, fertilization, cleavage and development of bovine oocytes. $J$ Reprod Fertil, 86:501-506.

Gardner DK, Wale PL. 2013. Analises of metabolism to select viable human embryos for transfer. Fertil Steril, 99(4):1062-1072.

Gioso MM, Costa EP, Fernandes CAC, Torres CAA, Carvalho GR. 2005. Perfil de progesterona e intervalo ao estro de receptoras bovinas sincronizadas com doses reduzidas de cloprostenol [in Portuguese]. Rev Bras Zootec, 34:1181-1187.

Gordon I. 1994. Laboratory Production of Cattle Embryos CAB International, Cambridge UK: University Press.

Haas GTS, Fernandes CACF, Costa EP, Torres CAA, Marques PAF, Lopes FG, Paula TAR. 2007. Taxa de prenhez e concentração sérica de progesterona em novilhas receptoras de embrião tratadas com somatotropina recombinante bovina ( $\mathrm{rbST})$ [in Portuguese]. Ceres, 54(311):26-32.

Hoelker M, Schmoll F, Schneider H, Rings F, Gilles M, Tesfaye D, Jennen D, Tholen E, Griese J,Schellander K. 2006. Bovine blastocyst diameter as a morphological tool to predict embryo cell counts, embryo sex, hatching ability and developmental characteristics after transfer to recipients. Reprod Fertil Dev, 18:551-557.

Hoffmann RP. 1987. Diagnostico de parasitismo veterinário [in Portuguese]. Porto Alegre: Sulina, 156p. Knijn HM, Gjorret JO, Vos Plam Hendriksen PJM, Van Der Weijden BC, Maddox-Hyttel P, Dieleman SJ. 2003. Consequences of in vivo development and subsequent culture on apoptosis, cell number, and blastocyst formation in bovine embryos. Biol Reprod, 69:1371-1378.

Lane M, Gardner DK. 1997. Nonessential amino acids and glutamine decrease the time of the first three cleavage divisions and increase compaction of mouse zygotes in vitro. J Assist Reprod Genet, 14:398-403.

Lazzari G, Wrenzycki C, Herrman D, Duchi R, Kruip T, Niemann H, Galli C. 2002. Cellular and molecular deviations in bovine in vitro-produced embryos are related to the large offspring syndrome. Biol Reprod, 67:767-775. 
Levy RR, Cordonier H, Czyba JC, Guerin JF. 2001. Apoptosis in preimplantation mammalian embryo and genetics. Ital J Anat Embryol, 106:101-108.

Li CY, Lee JS, Ko YG, Kim JI, Seo JS. 2000. Heat Shock Protein 70 Inhibits Apoptosis Downstream of Cytochrome c Release and Upstream of Caspase-3 Activation. J Biol Chem, 275:25665-25671.

Lindner GM, Wright Junior RW. 1983. Bovine embryo morphology and evaluation. Theriogenology, 20:407-416.

Lonergan P, Rizos D, Kanka J, Nemcova L, Mbaye AM, Kingston M, Wade M, Duffy P, Boland MP. 2003. Temporal sensitivity of bovine embryos to culture environment after fertilization and the implications for blastocyst quality. Reproduction, 126:337-346.

Machado GM, Ferreira AR, Guardieiro MM, Bastos MR, Carvalho JO, Lucci CM, Diesel TO, Sartori R, Rumpf R, Franco MM. 2013. Morphology, sex ratio and gene expression of Day 14 in vivo and in vitro bovine embryos. Reprod Fertil Dev, 25:600-608.

Macmillan WH. 1998 Statistical models predicting embryo survival to term in cattle after embryo transfer. Theriogenology, 50:1053-1070.

Mantikou E, Youssef MAFM, Van Wely M, Van der Veen F, Al-Inany HG, Repping S, Mastenbroek S. 2013. Embryo culture media and IVF/ICSI success rates: a systematic review. Hum Reprod Update, 19:210-220.

Martin KL, Leese HJ. 1995. Role of glucose in mouse preimplantation embryo development. Mol Reprod Dev, 40:436-443.

Morales H, Tilquin P, Rees JF, Massip A, Dessy F, Van LA. 1999. Pyruvate prevents peroxide-induced injury of in vitro preimplantation bovine embryos. Mol Reprod Dev, 52:149-157.

Mori M, Otoi T, Suzuki T. 2002. Correlation between the cell number and diameter in bovine embryos produced in vitro. Reprod Domest Anim, 37:181-184.

Pedersen ME, Ozdas OB, Farstad W, Tverdal A, Olsaker I. 2005. Effects of bovine oviduct epithelia cells, fetal calf serum and bovine serum albumin on gene expression in single bovine embryos produced in the synthetic oviduct fluid culture system. Reprod Fertil Dev, 17:751-757.

Pereira DC, Dode MAN, Rumpf R. 2005. Evaluation of different culture systems on the in vitro production of bovine embryos. Theriogenology, 63:1131-1141.

Pfaffl MW, Georgieva TM, Georgiev IP, Ontsouka E, Hageleit M, Blum JW. 2002. Real-time RT-PCR quantification of insulin-like growth factor (IGF)-1, IGF-1 receptor, IGF-2, IGF-2 receptor, insulin receptor, growth hormone receptor, IGF-binding proteins 1, 2 and 3 in the bovine species. Domest Anim Endocrinol, 22:91-102.

Ponsuksili S, Tesfaye D, El-Halawany N, Schellander K, Wimmers K. 2002. Stage-specific expressed sequence tags obtained during preimplantation bovine development by differential display RT-PCR and suppression subtractive hybridization. Prenat Diagn, 22:1135-1142.

Rafferty Junior KA. 1970. Methods in experimental embryology of the mouse. Baltimore: The John Hopkins Press, pp.23-29.

Rieger D. 1992. Relationships between energy metabolism and development of early mammalian embryos. Theriogenology, 37:75-93.

Riley JK, Moley KH. 2006. Glucose utilization and the PI3-K pathway: mechanisms for cell survival in preimplantation embryos. Reproduction, 131:823-835.

Rizos D, Gutierrez-Adan A, Perez-Garnelo S, de La Fuente J, Boland MP, Lonergan P. 2003. Bovine embryo culture in the presence or absence of serum: implications for blastocyst development, cryotolerance, and messenger RNA expression. Biol Reprod, 68:236243.

Sagirkaya H, Misirlioglu M, Kaya A, First NL, Parrish JJ, Memili E. 2006. Developmental and molecular correlates of bovine preimplantation embryos. Reproduction, 131:895-904.

Sampaio IBM. 2002. Estatística aplicada experimentação animal [in Portuguese]. $2^{\mathrm{a}} \mathrm{ed}$. Belo Horizonte, Fundação de Estudo e Pesquisa em Medicina Veterinária e Zootecnia (FEPMVZ). 265p.

Smith R, McLaren A. 1977. Factors affecting the time of formation of the mouse blastocele. $J$ Embryol Exp Morphol, 41:79-92.

Sociedade Internacional de Transferência de Embriões (IETS). 1998. Manual of the International Embryo Transfer Society.

Taylor WG. 1984. Toxicity and hazards to successful culture: cellular response to damage induced by light, oxygen or heavy metals. In: Patterson Jr MK. Uses and standardization of vertebrate cell cultures. In vitro monograph, n.5. Gaithersburg, MD:Tissue Culture Association, pp.58-70.

Thompson JG. 2000. In vitro culture and embryo metabolism of cattle and sheep embryos - a decade of achievement. Anim Reprod Sci, 60-61:263-275.

Universidade Federal de Viçosa (UFV). 1999. SAEG Sistema de análises estatísticas e genéticas. Versão 8.0.Viçosa [in Portuguese], MG: 1999. 59p. (Manual do usuário).

Vanda Ele L, Mateusen B, Maes DGD, Kruif A, Van Soom A. 2007. Temporal detection of caspase-3 and -7 in bovine in vitro produced embryos of different developmental capacity. Reprod Fertil, 133:709-718.

Vanroose G, Van Soom A, De Kruif A. 2001. From coculture to defined medium: State of the art and practical considerations. Reprod Domest Anim, 36:25-28.

Viuff D, Hendriksen PJM, Vos PLAM, Dieleman SJ, Bibbiy BM, Greve T, Hyttel P, Thomsen PD. 2001. Chromosomal abnormalities and developmental kinetics in in vivo-developed cattle embryos at days 2 to 5 after ovulation. Biol Reprod, 65:204-208.

Whittingham DG. 1971. Culture of mouse ova. J Reprod Fertil Suppl, 48:7-21.

Zhang B, Penagaricano F, Driver A, Chen H, Khatib H. 2011. Differential expression of heat shock protein genes and their splice variants in bovine preimplantation embryos. J Dairy Sci, 94:4174-4182.

Zhu HB, Zhang ZH, Fadlalla E, Wang RX, Geng DF, Liu RZ. 2014. Culturing surplus poor-quality embryos to blastocyst stage have positive predictive value of clinical pregnancy rate. Iran J Reprod Med, 12(9):609-616. 